\title{
ARTISTIC COGNITION IN SECONDARY SCHOOL LITERATURE LESSONS
}

\author{
Daiga Celmiña \\ University of Latvia, Latvia
}

\begin{abstract}
The subject of Literature studies is connected with the specifics of literature as the art of words and the cognitive abilities of the particular age group. It is crucial that the cognitive process during Literature lessons has a personal significance for the pupils, therefore the teacher should engage in artistic cognition together with the pupils, taking up activities that aim to develop creativity and co-creation. Creative tasks in Literature lessons not only develop logic, rationality and analytical skills; creative tasks help to involve pupils in imaginative, emotional and reflective processes. Such activities cultivate critical thinking and associative skills, stimulate imagination and encourage self-discovery and self-expression. Concepts, opinions and conclusions are not the only cognitive forms - there are images (creative mental models) and thought experiments as well. Therefore, the process of studies can be both reproductive and productive; problem solution, analysis and synthesis using literary fiction and, interdisciplinary, other arts, is at the very heart of artistic cognition process as applied to Literature studies. Solution of unconventional tasks posed by fiction studies requires not only critical thinking, but also creativity and creation of new values. During Literature lessons, the teacher encourages the pupils to engage in artistic cognition correspondent to the needs and abilities of their age group, taking into account the importance of stimulating pupils' aesthetic needs in a value-oriented learning process, development of pupils' artistic perception and creative thinking, reproductive and productive imagination, cultivation of artistic empathy and compassion, development of artistic analysis skills, collaboration, encouragement of self-discovery and self-expression.
\end{abstract}

Keywords: creativity, empathy, imagination, Literature studies, artistic cognition, self-expression.

\section{Introduction}

Pedagogical requirements to the quality of the study process have always been high and evolving in attempt to discover, explore, facilitate the development of harmonic, comprehensively developed biopsychosocial personality. In the tense setting of the competence-based education reforms in the $21^{\text {st }}$ century, discussion on the role of artistic pedagogy, the cultural understanding of pupils, the self-expression in arts and the role of Literature subject in the learning process involves pedagogues, parents, 
pupils, and representatives of various professions. The role of art and culture in today's world has changed radically. We live in a time where every member of society is simultaneously both consumer and creator of culture. Technological development imposes a need to be creative. At the same time, the world we live in is becoming increasingly complex, we have ever fewer answers, and contemporary art is one of the ways we try to explore and understand our place in the world. Art is an important form of expression of creative freedom.

In the $21^{\text {st }}$ century there is a peculiar tendency that, on the one hand, populistic slogans like "The world continues to change dramatically, but education does not adapt quickly enough!" or "Pupils are not prepared to deal with the challenges of the modern world!" are gaining popularity. On the other hand, many classical pedagogical conclusions are in a kind of renaissance, as evidenced by discussions and polemics in both scientific journals and mass media. Even OECD researchers emphasize the importance of creativity and creation in reference to what Albert Einstein has said: "Imagination is more important than knowledge. For knowledge is limited to all we now know and understand, while imagination embraces the entire world, and all there ever will be to know and understand" (Fadel, et al, 2015).

In some countries, teaching of art and design is included in general education as an important part of the training in science, technology, engineering, and mathematics (STEAM), i.e. practicing symbiosis of arts and these fields. Since art is an important resource for the development of intelligence and thought, it should not be taught by teachers by means of complementing positions according to the following principle: if a certain teacher needs more work load, a teacher of geography, natural sciences or other subjects, after doing some additional training, can become, for example, a teacher of visual arts (Bunkše, 2017). This idea can be supplemented by the realization that even a teacher of Literature should have a high qualification because in order to understand and analyse literary fiction or to assess the artistic creativity of pupils the teacher needs in-depth knowledge of literary and other arts, a pedagogue's qualification and experience, and knowledge of the psychological processes of making a work of art, as well as the specific development features of the particular age group of the pupils. Latvian Doctor of Pedagogy Anita Skalberga (2012) emphasizes the important role of Literature teachers, since literature is the facilitator of personality development, understanding of the world, aesthetic values and emotional intelligence, thus promoting engagement in culture.

The Literature study process is related to the specific nature of literature as cognition of the art of words and to the ability of artistic cognition of 
pupils at a given age. In Literature lessons it is essential that the cognitive activity becomes a personally important process for the pupil, so it would be advisable for the teacher to organize cooperation in pedagogically artistic activity and to engage pupils in artistically orientated cognitive activities aimed at creating, co-creating and development of a new subjectively and socially meaningful self-experience.

The paper follows the cultural-historical approach, the operational and systemic approach, and the following methods are used: theoretical analysis of pedagogical literature and discovering interrelations, analysis of self-experience.

\section{Literature as a study subject of the art of words}

Art as a part of intellectual culture includes the main areas of artistic activity, i.e. fine arts and music, literary fiction and dramatic arts, etc., but in the broader sense art or artistry is associated with many areas of human life and activity. In Literature studies, it is important to observe the specific nature of literature as art of words, where "work of literary fiction is a special figuratively conditional text, its comprehension in its perception is closely related to feeling, imagination, associations" (Rudzītis, 2000).

Jānis Anspaks (2006) acknowledges that the fundaments of art pedagogy are reinforced by the notion that personality formation should be viewed as a whole, capturing in conjunction the emotional and the rational spheres, and he emphasizes that the native language and literature lay the foundations for children's artistic upbringing; therefore it is important to abandon the over-rationalisation of the Literature teaching process, focusing mainly on cultivation of imagination and feelings instead. One of the responsibilities of teachers of native language and literature is to reveal the magic of the mother tongue, to deliver aesthetic pleasure and satisfaction of problem solving to pupils through literary fiction. Art subjects open up opportunities to expand pupils' artistic horizons, as well as cause deep aesthetic experience and pleasure. "Fetishizing the scientific path in cognitive process and personality development, neglects emotional education, artistic education, and in-depth acquisition of intellectual and aesthetic values." (Anspaks, 2006, 96).

Ausma Špona (2006) recognizes that the effect of art and literary fiction on person occur with every element of it - word, sound, rhythm, colour, line, shape. "The artistic cognition allows pupils to explore themselves in a creative activity, to comment of what they have seen and experienced in themselves (Špona, 2006, 116). The young person learns to understand things and phenomena only when these are personally important to them. 
It is essential that for the pupil the achievement of the learning goal is interesting, that the pupil experiences feelings and emotions, that learning gives them satisfaction, that studies are enjoyed as a process of personality fulfilment and improvement of the self (Maslo, 2003).

Each generation perceives a text in its own way, therefore one should not think of any "absolutely correct" reading or determining anything unambiguous in the Literature study process. Understanding the meaning of literary works is also subject to dynamism, it develops and evolves. The more successful the teacher is in helping each pupil's reader experience, the more they will be able to understand the literary work (Skalberga, 2012). With the understanding of the text, the pupil also reveals his attitude to the world, because the emotional sphere plays a major role in human life and thought. "The subject of literature is not a course in literature theory and literature history. It consists mainly of literary fiction as works of art of words, and of the associated artistic potential. If ignored, Literature in school becomes a general education subject and does not retain the specific features of the art of words. It preserves educational opportunities, but loses the opportunities of artistic upbringing orientation of values" (Rudzìtis, 2000, 52).

Despite the fact that the importance of Literature lessons in Secondary School is still under discussion in Latvia, Literature studies are now particularly topical there because:

1) nowadays the perception of texts has become more complicated in terms of content, form and emotional contradiction;

2) greater activity and stronger imagination are expected from the reader of modern literature;

3) for the text comprehension by a reader, not only the outside world experience is essential, but also their own inner world experience (including their wishes, fears, fantasies), which should also be developed and used;

4) in the lessons of Literature, the formation of the world view of pupils is promoted and the pupil as a reader is being prepared to creatively use acquired knowledge and skills in their future lives; the competence of the pupil as a reader is expanded;

5) when reporting on what has been read, the pupil expresses their attitude towards the world;

6) Artistic cognition in Literature lessons promotes the pupil's general competence to work with abstractions, such as ideas, symbols, images (National Centre for Education).

In his studies and recommendations on the Literature teaching methodology, Jānis Rudzittis (2000, 111) emphasizes the need for the development of the professional competence of Literature teachers, because 
the Literature teacher needs a well-developed pedagogical thinking and pedagogically artistic thinking strategy in order to be able to encourage and develop the following in pupils:

- aesthetic needs;

- artistic perception (artistic associations related to it, co-creation, artistic emotional experience, artistic analysis);

- artistic contact, also self-exploration (formation of value orientation);

- catharsis as a self-decontamination of complex feelings in empathy;

- artistic appreciation of the facets of the beautiful and the good.

Interaction with art, including literature as art, is to be developed, cultivated. Lev Vygotsky (1965) emphasizes that the effect of art is not "mechanical", but rather reinforced by the active participation of the personality itself. Otherwise, the intellectual aspect of art is lost. Furthermore, Jānis Anspaks (2006) says by a scientific metaphor: "It is complicated to unleash in oneself the highest manifestations of aesthetic activity, i.e. the ability to very consciously protect, nurture and create beauty, to determine one's way to aesthetic self-upbringing, self-education and self-development, using the possibilities of exploration of the beautiful and the true where the word as an indispensable means of cognition, activity, interaction and creation is of a great importance. It is with a word that the cognitive exploration path begins and ceaselessly continues to grow, by discovering the uncharted, the unfelt, the unprecedented. The aesthetic, the beautiful, the artistic gives this miraculous power to a word" (Anspaks, 2006, 91).

The former Latvian Minister of Culture from 2013 till 2019 Dace Melbārde in an interview at a Latvian Television show on culture said: "I believe that the role of education is not only to develop each individual's personality, but also to preserve the national values, to enrich them. All the values that make Latvia - the Latvia. In general, the country's development is dominated by exact issues, economic development, which is, of course, understandable and reasonable, but the basis of any development, whether it is state development or personal development, there must be harmony, balance, for economic development is worth nothing if it does not make us to be cultural people, for example, or does not lead to cultural enrichment. Education should produce both intelligent and creative people. People who respect their cultural values and who are able to pass them on to future generations" (Verhoustinska \& Kaminska, 2018).

Learning is a lifelong process, both at school and outside of it, at work and at leisure time. Learning is individual but also social and cultural. Learning is also a cognitive process in which the social and cultural dimensions play important roles. This is important in all areas of learning, especially in areas related to language learning types, as linguistic communication is 
a social and cultural process. Only the combination of the emotional and the rational makes learning to be important (Maslo, 2003). A pupil from the last year of Secondary School, thinking of the importance of Literature studies, writes: "With the help of literature people get an idea of the world, other people, relationships, but most importantly -their inner world, their pains, doubts and experiences, about values acquired and sometimes lost." (Inga [Name changed], $12^{\text {th }}$ grade).

There is no common understanding of pedagogy, education science, pedagogical psychology, art, or of the essence of culture in the world. Also, the teaching methodology is not based on any one universally productive learning model, but it drives the thinking of teachers so that, in accordance with their professional competence, they seek and find optimal ways of their cooperation with their pupils (Rudzitis, 2000, 46). Creativity in the learning process is tied with collaboration and interdisciplinarity, where understanding the meaning of the text, imagination, seeing the actual issue, ability to learn independently, using reasoning skills in writing, and being open to new experiences that drive pupils towards subjective search for meaning are all essential. The creative Literary tasks are not only related to logical, rational, analytical activity, for creative tasks help pupils to get involved in artistic-oriented cognitive activity that promotes problem-thinking, evokes associations, emotions, develops imagination, and is oriented towards awareness of values important to themselves and society, and towards self-discovery and self-expression in action. Therefore, the authors of the Latvian "School 2030" educational reform, who were seeking cross-disciplinary complementation of the Literature and Sport, and Literature and Physics subjects, could be advised to do it on pedagogically sound basis, by assessing the experience of our national pedagogy in the Literature teaching methodology, by giving the literature teaching process an important role in the realm of cultural awareness and taking into account the specific and different nature of the artistic knowledge process of the Literature studies from the process of intellectual cognition in subjects, such as Science, for example. One of the tasks of the Literature teacher is to develop self-activity and self-expression of pupils in an artistically directed cognitive action.

\section{Artistic cognition in Secondary School Literature lessons}

If the focus of the learning process is not on the content and the outcome of learning, but rather on the individuality of the pupil's personality and on cooperation, then the essence of the educational process is related to the approach of personality activity, where cognitive activity is the basis of the learning process. Jean Piaget also reminds the importance of a learning 
process oriented towards the pupil's internal and individual activity, where "the child always learns actively by interacting with their environment, creating ever more complex thought structures" (2002).

Learning is one of the most complex human activities, the outcome of which depends not only on the ability to learn and on attitudes towards it, but also on the mental abilities altogether, on the attitudes and assistance of others, on the adequacy of teaching aids. Thus, learning is not just an activity of the mind, it is strongly influenced by non-intellectual processes, such as emotions, motives, interests (Žogla, 2001, 220).

Cognition is traditionally explained as a process of human creative activity, inseparably linked to the social and historic experience which is a- reflection of objective reality in human consciousness. In the process of cognition, a person acquires new knowledge of the world on the basis of which the aims and motives of human activity arise. The basis of cognition is practical experience. Cognition as a socially conditioned cultural and historical process cannot exist or develop beyond interaction and activity.

In art pedagogy, the understanding of interplay between scientific and artistic cognition is essential in the process of forming a comprehensive personality. Jānis Anspaks (2006) points out that several types of cognition can be distinguished: the everyday, the artistic, and the scientific, in which the word has a leading role. Bringing the benchmark of scientific reference to the forefront and leaving non-scientific cognition possibilities in the "shadow" lead to one-sidedness in the learning process. The revelation of the scientific and artistic cognition features and the defining of their interaction in the personality development during a learning process is very topical in art pedagogy, not forgetting that education is not just a rounded amount of knowledge, but one is encouraged to ensure a harmonious and balanced development. This also fully applies to the choice of cognition styles and the specialization of the child (adolescent, youth, adult) in relevant cognition activities. "It is important to emphasize the most essential difference between art and other forms of world cognition. If science captures the world scene in concepts, theories, abstract categories, then art expresses the world in images. Therefore, the (beautiful) perception and understanding of art begins with the specific means of figurative thinking and with their perception. A character is a technique of inquisitive reproduction and generalization of the beautiful from the position of aesthetic ideal, thus reflecting the world in a distinctly perceptible, directly perceived form." (Anspaks, 2006). Figurative thinking is needed in all forms of cognition, it is not only related to the field of art; the cognition process is unified; however, the learning of each field is characterized by a different choice of pedagogical means in the teaching and upbringing process. 
Irēna Žogla (2001) also emphasizes in her studies that by understanding the essence of studies, three types of cognition have to be compared: Practical cognition, Scientific cognition and Learning cognition. Practical cognition is learning by doing, it is always concrete and unique, repetition is based on the knowledge and skills already acquired. Scientific cognition is a very targeted way of cognition, intense discovery of objectively new relations, rules. The foundation for the discovery of the new is Learning cognition. A Learning cognition is a specially, purposefully organized, intense cognition method that takes place with the help of a teacher and purposefully prepared teaching aids, it is the discovery of the subjectively new (Žogla, 2001, 223). All types of cognition are united by the aim of discovering the essence of things and phenomena, internal rules, interrelation of structural components for practical use of this knowledge or for acquiring new knowledge.

In turn, Ausma Špona (2006) adds that Learning cognition is acquisition of subjectively new knowledge, skills and attitudes within a specially organized pedagogical process where new, subjectively and socially significant self-experience arises. She points out that a learning cognition can also be seen as an artistic cognition, since the cognition is generally an intellectual process, where perception also takes place through the senses, feelings, characters, concepts. The artistic cognition allows the pupils to explore themselves in creative activity, to express their appreciation of the seen and experienced. The artistic cognition encourages both attitude and intellectual development by perceiving, analysing and understanding a work of art in a personally significant emotional experience. It forms a habit of viewing, listening, acting creatively, analysing and emotionally perceiving a work of art, of contemplating traditional and art values. It is important to cultivate in pupils a need for art values, that is a skill to evaluate; to perceive a work of art; to create art values, which are components of educational content that ensure the formation of positive attitudes towards art (Špona, 2006).

The logical path of cognition (perception, imagined character, realization, application) is peculiar in the study process, for learning is not only an activity of the mind, it is also strongly influenced by emotional processes, such as emotions, motives, interests. Based on pupils' experience and abstract thinking, it is possible to achieve intensity in action. The learning process depends on what aspect of cognition is chosen as its basis. The essence of learning is that a theoretical or practical learning task can be solved only within the realistic possibilities of the pupil, respectively based on the developed learning skills, knowledge of a particular subject or subject group, the quality of the development of cognition processes and attitude towards it (Žogla, 2001, 227). Doctor of Art Aija Freimane in 
an interview on the role of artistic cognition in education acknowledges that "Today the ability to perceive and notice, the ability to watch and reproduce is an important part of interdisciplinary education, innovation and collaboration between different professionals" (Bunkše, 2017).

At Secondary School, within the age group of 15 to 18-year olds), needs and cognitive development are associated with a new environment and requirements, as well as the young person's progress towards their profession, resulting in a need for certain behavioural, emotional and value autonomy. Autonomy of values means that in early youth there is a need and a right to having their own opinions, even if these views are still in formation, and often very categorical (Šteinberga, 2013). The Literature learning process offers great philosophical issues of life and a path to forming, formulating and defending oneself and one's opinions through literary fiction as an individual cognition action, as well as in cooperation, and encourages the aesthetic needs of pupils in value-oriented learning process. Vilnis Purēns draws attention to the importance of inquisitive interest during the learning process and concludes that "In adolescence, inquisitive interests are characterized by operation with abstract phenomena, experiments with selection of interest object, domination of self-affirmation needs, need for awareness of ones' independence, emphasis on the importance of outcome and social evaluation, orientation of interests towards humanitarian fields (Purēns, 2017).

Another pupil of the last Secondary School year in their consideration of "My Searches and Discoveries in Literature," emphasizes what is important for him in fiction, Literature lessons, and the cultural space as a whole: "I expect and seek an opportunity to manifest myself in the cultural environment. It brings new experiences and perspectives; from it I have acquired both academic knowledge and life knowledge. I am looking for something more in culture and literature than just what can be useful for an essay in a Literature lesson, but also for what develops my mind and makes my personality more intelligent. In the end, I am simply looking for how to spend time meaningfully and develop myself. I have attended poetry readings, classical and alternative cinema and theatre performances, music concerts, art exhibitions. I am genuinely interested in the creative part of humanity." (Gundars [Name changed], 12th grade).

Quality learning in Literature classes takes place if each pupil can develop their abilities and talents, find a way of learning appropriate to their learning skills and traits, the needs of the pupils are taken into account in the learning process, and the teacher is a consultant, assistant, but the pupil is independent and mainly responsible for their own learning. The Literature learning process is not confined to logical, rational, analytical action, since pupils are involved in an imaginatively emotional, evaluative 
artistic cognition that promotes problem solving, encourages associations, develops imagination, directed to self-discovery and self-expression in action. Latvian painter Džemma Skulme, upon receiving the Purvitis Prize for a lifetime contribution to art, said: "The mission of art is to expand fantasy and thought and to put the soul area in action" (Kušķe \& Latvian Public Broadcasting, 2019).

\section{Conclusions}

The Literature study process develops pupils' artistic perception and imaginative thinking, pupils' imagination, encourages artistic empathy, empathic experience, develops artistic analysis skills, critical thinking, cooperation, promoting creativity, self-exploration and self-expression, and fostering national identity awareness in the global cultural space.

The artistic cognition of Literature study process is aimed at both acquiring new knowledge and skills and at promoting creativity and creation in pupils. Creativity in the Literature lessons as an art subject can take different forms: as creativity and artistic creation, as well as critical thinking and creative problem solving.

Forms of thought are not only concepts, judgments, conclusions, but also images (imaginary models) and thought experiments. Thus, learning activity can be both reproductive and creative, and it is the artistically orientated cognition process where the focus is on the Literature learning process dealing with problems, analysis and synthesis using fiction and other arts through interdisciplinary principle.

Jānis Anspaks (2006) and Jānis Rudzītis (2000) have made a major contribution to Latvian artistic cognition research and Latvian art pedagogy, including literature as the basis of art of words, emphasizing the importance of the Literature teacher's professional competence and reminding that it is essential in Literature learning process to recognize the specific features of literature as an art of words where artistic cognition allows pupils to explore themselves in creative, personally meaningful activity, discovering and expressing their attitude towards the world, developing and cultivating their intellect.

Literature teacher in Literature lessons encourages pupils to engage in artistically oriented cognition activity that is appropriate to pupils' development needs and abilities, where it is important to encourage pupils' aesthetic needs in value-oriented learning process, to develop pupils' artistic perception and imaginative thinking, imagination, to encourage artistic empathy and empathic experience, to develop artistic analysis skills, cooperation, to promote pupils' self-exploration and self-expression. 


\section{References}

Anspaks, J. (2006). Mākslas pedagoóija. 2. daḷa. Metodologíija. Teorija. Prakse. [Art Pedagogy. Part 2. Methodology. Theory. Practice]. Rìga, Latvia: RaKa.

Bunkše, I. (2017). Intervija ar Andri Teimani. Akadēmija un mākslas izglītība [Interview with Andris Teimanis. Academy and Arts Education]. Studija, 109, 14-18.

Fadel, C., Bialik, M. \& Trilling, B. (2017). Četru dimensiju izglïtiba [Four-dimensional education: The Competencies learners] (Lielvārds, Trans.), Rīga, Latvia: Lielvārds. (Original work published 2015).

Kuške, B., \& Latvian Public Broadcasting. (2019). Interese par visu skubina nesašlıkt. Saruna ar mākslinieci Džemmu Skulmi [Interest for everything motivates to not give up. Interview with artist Džemma Skulme]. Latvian Public Broadcasting. Available from https://bit.ly/2Ei8X2M

Maslo, E. (2003). Mācīšanās spēju pilnveide [Improvement of learning abilities]. Rīga, Latvia: RaKa.

Piaget, J. (2002). Bērna intelektuālā attistiba. [La construction du réel chez l'enfant] (Meinerte, S., Trans.) Rīga, Latvia: Pētergailis. (Original work published 1937).

Purēns, V. (2017). Kā attīstìt kompetenci [How to develop proficiency]. (43-106). Riga, Latvia: RaKa.

Rudzītis, J. (2000). Literatūras mācïbas skolā. Metodisks rosinātājlïdzeklis esošajiem un topošajiem literatūras skolotājiem. [Literature studies at School. Methodological and motivational tool for present and future Literature teachers]. (46-121). Rīga, Latvia: RaKa.

Skalberga, A. (2012). Vidusskolēna literārās kompetences veidošanās [Formation of HighSchool Student's Literary Competence]. (Doctoral dissertation). Available from DSpace. LU database (URI Identifier https://dspace.lu.lv/dspace/handle/7/4834).

Špona, A. (2006). Audzināšanas process teorijā un praksēe [Upbringing Process in Theory and Practice]. (116-117). Rīga, Latvia: RaKa.

Šteinberga, A. (2013). Pedagogiskā psihologija [Pedagogical psychology]. (115-125). Rìga, Latvia: RaKa.

Verhoustinska, H. (Writer), \& Kaminska, Z. (Director). (2018, November 30th). Valdība apstiprina jaunu izglìtības standartu. Ko tas nozīmē skolām? [Government approves a new standard of education. What does this mean for schools?]. [Television series episode] In LTV1 (Producer), Kultūršoks. Rīga, Latvia: Latvian Television.

Vygotsky, L. S. (1965). Psichologija iskusstva [Art psychology]. Moskva, Russia: Iskusstvo.

Žogla, I. (2001). Didaktikas teorētiskie pamati [Theoretical Background of Didactic]. Rīga, Latvia: RaKa. 